\title{
How to Activate Students' Learning Initiatives in Bilingual Teaching of International Finance
}

\author{
Zheng Yingfei \\ School of Finance \\ Shanghai University of International Business and \\ Economics \\ Shanghai, China \\ Yfzheng2003@163.com
}

\author{
Chen Xiaojing \\ School of Finance \\ Shanghai University of International Business and \\ Economics \\ Shanghai, China
}

\begin{abstract}
The "International Finance" course is a foreignrelated course, and is characterized with high theoretical and practical requirement. This course is suitable for bilingual teaching, but the difficulty is that students must learn both language and business. The aim is to activate the students' learning initiatives. It introduces a variety of teaching methods such as real example teaching, experimental simulation teaching and case analysis competition teaching. And it also recommends optimizing the proportion of teaching language in English or in Chinese according to teaching content and students' acceptance, to choose imported textbook but supplement with Chinese financial cases. And finally suggests keeping communication with students after school. It is an innovation of teaching method.
\end{abstract}

Keywords-international finance; bilingual teaching; activation state; teaching method

\section{INTRODUCTION}

The United Nations Educational, Scientific and Cultural Organization (UNESCO, 1998) suggests that today's education is no longer providing information to students, but rather cultivating active thinker of the twenty-first century. Therefore, good education is not "spoon-fed", but to activate the student learning initiative by the student-centered teaching process.

Take the "international finance" course as an example. If students fail to experience the various scenes of international financial activities, the students will feel difficult to learn. But the reality is that most students have rarely touched on foreign exchange and related international financial activities in the past, which requires instructors to break the limited conditions inside and outside the classroom to guide students to the corresponding financial scene. In the past teaching experience, the author found that there are always a few students in the classroom who are very hard-working, but the learning effect is not good. They are characterized by attentive listening, taking notes, and initiatively asking the instructor their doubts. We can see that they are typical good students. But through communication the instructor found that their problems mainly from their limited knowledge of the corresponding financial activities. Financial knowledge is derived from the financial activities itself and the formation of common sense, rules and theory and its application. Lack of the most basic practical

Project supported by the National Natural Science Fund Project (71303153), Shanghai Municipal Commission of education scientific research innovation project "(project number: 14ZS149), and the Shanghai Municipal Education Commission English demonstration course" Risk Management of Commercial Banks ", the Shanghai Municipal Education Commission key course of" commercial bank management ". experience, will cause great difficulty in understanding financial knowledge, and also cause lack of learning motivation. If a student cannot answer the question "What does the instructor's question matters to me?" "Why should I care about it?" He or she cannot come to a very active learning state. Some students even think that "the University taught knowledge is out of touch with the society," and "in the future when we go to the society, the university taught knowledge has no use." If students hold such a negative point of view, they are not active learning.

For the "international finance" course, if the students can deeply realize that I am in the financial environment which the course covers- macroscopically, the monetary system, exchange rate arrangement, etc. will affect our benefits and decision-making, and now I can participate some trading activities, such as foreign exchange transactions, in the future I will help enterprises and my own international investment and financing, we solve the fundamental problem of learning motivation, and also solve the problem of understanding more than half of the difficulties. In this way, every student will be activated, the efficiency of learning is also improved, and the knowledge learned is alive, not out of touch with practice. To this end, instructors should create a student as an immersive environment, more books and real financial activities linked to the more set up some practical links.

This paper first analyzes the problems existing in the teaching of this course, and then focuses on how to activate the students' learning initiatives in the process of bilingual teaching of the "International Finance" course.

\section{II. "INTERnAtional FinANCE" Present Situation AND PROBLEM ANALYSIS}

\section{A. Learning Situation Analysis}

The main teaching object of this course is the junior students of our university. In this stage the students have certain basic knowledge of the financial theory, but it is not comprehensive enough, and the foundation is not strong enough. Their foreign language level is generally CET six level around, their interest in international finance is usually strong and their ability of acceptance is also strong. But all above abilities still need to strengthen, and some students are not selfmotivated. For this current situation, the instructors should 
design their guidance. It is important to guide students to learn more about the surrounding economic environment, especially the financial environment and to teach them the effective learning methods.

\section{B. Analysis of the Problem of Poor Practice Teaching}

At present, the practical teaching resources of this course are limited, so that the students can't really touch the social reality of international finance. The training of this course can't achieve the effect of controlling the practice process and guaranteeing the practice teaching. The new problems and new situations facing international finance are more and more comprehensive. With the deepening of China's economic opening degree, the international trade frictions are exacerbated and the international balance of payments becomes more and more concerned by the international community. The exchange rate of RMB fluctuates heavier than before. The impact is also far more profound, and even caused widespread concern in the domestic people. These new financial realities of China have not been formally introduced into the teaching system.

\section{Foreign Imported Textbooks and the Lack of Contradictions in China}

The use of foreign imported textbooks is conducive to students through the authentic English learning international financial theory, but foreign textbooks are often from the perspectives of the United States and other developed countries and have little research on China, even with nothing about China's recent reform and opening up practice. This is not conducive to students from the practice of understanding the content of the course, but also not conducive to students understanding China's international financial related issues such as China's exchange rate reform, opening up reform. And it is not conducive to students to explore China's participation in international financial activities and the formation of their own point of view and understanding.

\section{How to ACtivate THE StUdents' InItIATIVES IN BILINGUAL TEACHING OF THE "INTERNATIONAL FINANCE" COURSE}

\section{A. Introducing Concept by Real Story}

Giving example is a commonly used method by instructors to explain nouns or phenomena. But if you want students to pay attention to the instructor's case. Then this example should not be too theoretical and abstract, but should be very specific. It is best a story about their familiar people and things. The priority that can draw the attention of the student is that an abstract case is inferior to a specific one, and the actor in the case with no name is inferior to a case with a renowned or familiar actor. So to tell students about their own or familiar people's financial story is a good method to introduce financial concepts, so that students can link up the financial life of their own, families, or friends with the financial theory. For example, when talking about "foreign exchange risk", the author often tell her own foreign currency investment story. Typically, the author in the first half of 2008 had planned to invest in a package of foreign currency financial product, including the Euro and the Australian dollar. The funds require a quite high minimum amount of money and the author considered it is too risky to invest so heavy weight of her asset in such a high risk assets, so that give up in the end, which saved the author from heavy loss. In September of that year, the financial crisis came, although the foreign currency denoted yield is guaranteed, but because the exchange rate of Euro and the Australian dollar fell dramatically, the return denoted in RMB fell very seriously. The instructor's thrilling experience impressed the students very much. This story will allow the students to remember what foreign exchange risk is.

\section{B. The Practical Activities Throughout The Teaching Process}

It is useful to seize the current students' likes and the good use of the internet. It is good to recommend them to the corresponding website after the theory introduction. Such as recommend the IMF and the World Bank website after teaching the International Monetary System and the international financial institutions. For checking and communication, at the beginning of next class spend a few minutes to communicate with students about what they found from the website, and sometimes students will bring some small videos on the site and share.

The most representative of practical learning is the foreign exchange margin transactions. In the past several years, the course has gradually formalized the foreign exchange margin simulation transactions in the teaching program. From the earlier semester, we encouraged everyone to participate voluntarily, and then asked for all participation, and given certain assessment weight, such as $10 \%$. The specific proportion is still in the exploration. At present, the author's approach is to arrange the simulation trading after the concept introduction of the foreign exchange and forward foreign exchange, by designating a trading platform for students to open a simulation trading account (interface in English). The students are required to record each transaction analysis process, to timely summarize the previous transaction, and to submit a report after one-month transaction. During the onemonth transaction, the content taught in the classroom is the foreign exchange market, exchange rate decision theory and foreign exchange derivatives trading, so that the classroom teaching content is close to the simulation transactions. Both of them promote each other, and complement each other. Not only the transaction experience help the concept understanding, the theoretical knowledge also encourage the students to engage in transaction. In order to improve the enthusiasm of the simulation transactions, in the simulation transaction month, before each class the instructor arrange a few minutes for students to share the latest trading experience. The three indicators for the assessment of transaction are as follows: first are the results of foreign exchange transactions, according to the profit order. At the end of the transaction, the selection of "foreign exchange trading God" is a very concerned event. The second indicator is the logic of the report. Foreign exchange margin transactions are mainly affected by short-term factors. If students are able to find some exchange-sensitive information during the transaction and give a logical analysis, their scores can be increased. The third indicator is the participation of the trading experience sharing. Through the 
foreign exchange margin transaction activities, students get the initial trading experience, personal touch of the financial market risk and profit stimulation. Many students also develop a habit of focusing on financial information, self-learning financial investment skills. Therefore, in the same course interspersed with theory and experimental teaching are better than setting two courses separately.

\section{English Case Analysis Competition}

Bilingual teaching has one more goal than the mother tongue teaching that is to master the professional knowledge in another language. This paper suggests the idea of activating students' learning initiatives, and therefore activating students' enthusiasm of applying this foreign language. Theoretical and practical studies have shown that people is still not active enough to use foreign language just by listening and watching, but thinking and discussing in a foreign language can stimulate a higher level of activity. So the case discussion was introduced into the course. The course "International Finance" has several chapters that are suitable for the introduction of case teaching, but due to time constraints, usually only one of the chapters introduced one case in the author's class. The students competed in the case analysis by summiting reports and making presentation.

\section{Keep After-School Communication With Students}

In bilingual teaching, the students usually have more problem than that of traditional teaching. Therefore, only the classroom teaching cannot solve the students' questions, and the after-school communication is necessary. Through postclass communication, it is very easy to find many personalized problems and universality problems, which is very important to improve the teaching effect and improve the learning enthusiasm of students. With the gradual increase in the utilization of the network teaching platform, through this platform can effectively realize the exchange and interaction of instructors and students, and answer the students' various personal and universal problems. Instructors can also assign operations and correction operations, and can even have test and examination. Our practice shows that after-school informal discussion and participation in the network platform is a favorite way of learning by new generation of college students.

\section{SPECIFIC ISSUES OF BILINGUAL TEACHING IN THIS COURSE}

\section{A. Reasonable Arrangement in the Proportion of English and Chinese.}

What is the optimal proportion of Chinese and English language in teaching? Based on the higher requirement of foreign language level of the employees, the author thinks that the proportion of English teaching should be improved as far as possible, but not necessarily be completely English. Because there are several constraints on how to improve the proportion of English teaching. First of all, the overall level of English of the students is limited. Can't understand, and in-depth understanding of English teaching, followed by the instructor's English expression level, can't be arbitrary, can't speak in English vivid and interesting. Most bilingual instructors can use the English language to clarify the book, but can't achieve a lively and interesting. Students, for simple or have a certain basis for knowledge, generally understand, but the first time to accept some of the more difficult new knowledge, can't be well grasp. Therefore, it is easy to lead to bilingual teaching to improve foreign language skills but reduce the professional level of the results. In order to overcome these two constraints, as far as possible to improve the proportion of English teaching, the author's personal practice is mainly summed up in two: First, adhere to English learning, and second, the use of English teaching in a gradual manner. For example, at the beginning of the course, the author generally uses the Chinese language course to explain the new vocabulary. But with the students on this part of the framework of understanding, began to increase the proportion of teaching in English. Stressed, review, review the knowledge of the time, it is in English. First introduce the students into the door, and then penetrate the English expression, deepen understanding. The reason to do so is only a matter of interest. The best choice is to allow students to avoid the introduction of this link through the first Chinese. But the practice found to be able to do the review of students than the preview of the students more. They generally reflect that before the instructor taught, to see the original English textbooks are boring, or in their words, "very much need perseverance." Therefore, from the practical feasibility of the consideration, requiring students to review after school, read the text, with the inspection to check the link. Every class begins; there will be about 10 minutes of the whole English Q \& A. This part, through the well-designed questions to mobilize the initiative of the students, so that they answer their own questions, the contents of the last class to form a system impression, while achieving the purpose of checking the students to read the situation of teaching materials.

Another principle to determine the proportion of English in teaching is based on the content to determine. In terms of bilingual teaching of international finance, the proportion of English is relatively large in teaching foreign exchange market, foreign exchange risk management, international financial market, international financial institution and derivative trading part. In teaching international balance of payments theory, Exchange rate decision theory, monetary crisis theory, the international monetary system and other parts of the appropriate increase in the proportion of Chinese interpretation. The logic of the first few knowledge modules is relatively fresh, only the technical rules such as foreign exchange transactions can be, the English explanation is easier to understand, due to actual links, such as simulation transactions, case analysis of the background language are in English, but also omitted Language switching, so in teaching these modules, mainly in English teaching. But behind a few knowledge modules used more basic knowledge, such as currency banking, macroeconomics, etc., these students are generally taught in Chinese taught. These knowledge modules also require students to systematically analyze the problem, so it must be clear that the knowledge system and logical derivation are clear, so that some non-infiltration of Chinese and foreign interpretation is difficult to achieve this goal. 


\section{B. Selection of Teaching Materials}

The foreign imported textbooks have their advantages of frequent refreshing, rich in content, large amount of information, and other advantages, but also have a little regret. The original textbooks do not exactly match the syllabus of the domestic teaching. The former basically covers all the contents of the latter, but also covers multinational companies in the global financial management business. This content is taught in other courses but not required in this course, resulting in a few chapters being swept away. In the other hand, none of the Chinese financial cases is introduced in the foreign imported textbooks. So the latest case of China's participation in international financial activities should be supplemented by providing supplementary reading materials to students. Another common problem is that these foreign imported textbooks are generally translated into Chinese and have the corresponding Chinese version available. Many students tend to use the Chinese version. To a certain extent, it is contrary to the original intention of bilingual teaching. Because the nature of the course determines that, in the future practice of students, English is the target language, and is the tool language, so that should encourage students to overcome difficulties, and learn to apply the set of English expression and communication platform in the international finance field.

\section{CONCLUSIONS}

"International Finance" course is closely related to foreign business, and covers fundamental and practical issues, so that the course is suitable for bilingual teaching, and the students face the difficulties of learning both language and business. This article based on the author's four-year "international finance" bilingual teaching, after the exploration of some teaching methods, proposed some viewpoints. In the author's view, the application of all teaching methods is to meet one purpose - to activate the learning initiatives of students. To this end, the introduction of real examples in teaching, experimental simulation teaching, case analysis competition teaching and other methods are recommended.

This structured teaching method, which activates the students' initiatives, encounters a small number of difficulties in practice, but is largely overcome by careful design and strong collaboration with students. First of all, the simulation trading practice takes students more extra time, and some students at first was surprised by this "unorthodox" learning method, but in the end they have harvest by participating in these activities, and then understand and support it. Second, for instructors, these methods will increase the preparation time of the course. Especially for large-scale class teaching, extra teaching skills are needed. Furthermore they have to overcome the difficulties of ancillary information, equipment, and resources. Finally, the instructor's implementation of this structured teaching program is also at risk, including whether the student is willing to participate, the risk of some activities out of control, and the perceived risk of teaching methods. So the instructors need to implement a lot of efforts to improve the ability of having the situation under control, and it also needs the support of teaching management department.

\section{REFERENCES}

[1] Lu Sha. The application of autonomous learning model in bilingual teaching of international financial management $[\mathrm{J}]$. accounting monthly, 2010 (21): 97-99. (In Chinese)

[2] Yang Shuqin, Ma Xinying. The ability of the bilingual teachers of minority class teaching evaluation criteria to construct $[\mathrm{J}]$. China Education Journal, 2010 (7): 67-70. (In Chinese)

[3] Zhao Haiyan, Meng Qingxia. On the integration of market mechanism and the development of bilingual teaching in Chinese universities [J]. Business economics research, 2010 (16): 120-120. (In Chinese)

[4] Bonwell, Charles C. Eison, James A. Active Learning: Creating Excitement in the Classroom Z, ERIC Clearinghouse on, Higher Education Washington DC.| FGK28050 George Washington Univ _, 1991

[5] Alameddine M M, Ahwal H W. Inquiry Based Teaching in Literature Classrooms [J]. Procedia Social and - Behavioral Sciences, 2016, 232:332-337.

[6] Nian Liu, Liu Dongying. International finance course teaching reform way of [J]. Financial economy, 2016, (06): 136-137. (In Chinese)

[7] Han Li. The reform of teaching methods of international finance course [J]. Contemporary economy, 2009, (07): 118-120. (In Chinese)

[8] Zhang Yonghui, Meng province. The application of inquiry based learning method in the teaching of economics and management courses in Colleges and Universities: a case study of the teaching innovation of international finance $[\mathrm{J}]$, higher education forum, 2010 (4): 77-80. (In Chinese) 